\title{
WIZJA MIŁOŚCI MĘ̇̇CZYZNY I KOBIETY W PIEŚNI NAD PIEŚNIAMI. IMPLIKACJE PSYCHOLOGICZNO-PEDAGOGICZNE
}

Miłość między mężczyzną i kobietą jest tematem niezwykle głęboko obecnym w literaturze starożytnego Bliskiego Wschodu, a nade wszystko w Biblii Hebrajskiej, w której mówią o niej teksty Rdz 2-3; Oz 3-4 oraz cała księga Pieśni nad pieśniami (Pnp) i liczne Psalmy (por. cały numer Le monde de la Bible, 2001, nr 1). Od wieków znane są dwie zasadnicze interpretacje Pnp: naturalistyczna i teologiczna (ich syntetyczny przegląd podaje: LaCocque, 2001). Współcześnie proponuje się ich połączenie (Ricoeur, LaCocque, 1998, s. 410-430). Miłość ludzka opiewana w Pnp jest rozumiana jako symbol objawiający „coś” bardzo ważnego w odniesieniu do relacji Bóg - człowiek (miłujący się: mężczyzna-oblubieniec w Pnp reprezentujący Boga i kobieta-oblubienica reprezentująca lud Przymierza). Dzięki temu miłość „,naturalna” może być rozumiana jako doświadczenie ponad-naturalne, wręcz nadprzyrodzone. Ma to zasadnicze znaczenie także na płaszczyźnie psychologiczno-pedagogicznej.

W świecie współczesnym miłość między mężczyzną i kobietą nie tylko poddana jest licznym próbom, jak we wcześniejszych epokach, ale mocno zagrożona. Faktorów negatywnie oddziałujących na tę więź jest kilka. Najbardziej widoczne jest zacieranie różnic między tożsamością cielesno-duchową mężczyzny i kobiety. Równie dewastacyjny wpływ na psyche młodych ma ich ukierunkowanie, i to od najmłodszych lat, na produkty techniki, które zdają się zastępować obecność innych osób jako partnerów spędzania wolnego czasu, rozrywki, rozmowy, twórczych inicjatyw. Jeszcze innym negatywnym zjawiskiem $\mathrm{w}$ procesie wychowywania

Ks. prof. dr hab HenRYK WiTCZYK - Katedra Teologii Biblijnej Nowego Testamentu i Proforystyki, Instytut Nauk Biblijnych, Wydział Teologii Katolickiego Uniwersytetu Lubelskiego Jana Pawła II; Al. Racławickie 14, 20-950 Lublin; e-mail: henryk.witczyk@kul.pl 
młodych dziewcząt i chłopców jest coraz bardziej obecny w ich przestrzeni duchowej świat wirtualny, odrywający od rzeczywistości. Nie bez znaczenia dla miłości między mężczyzną i kobietą są dominujące w myśleniu o człowieku i jego szczęściu „filozofie”: egoizm, konsumpcjonizm i hedonizm. Te współczesne zagrożenia i niebezpieczeństwa dotyczące autentycznej miłości mężczyzny i kobiety, zwłaszcza wypaczenie wizji męskości i kobiecości są daleko groźniejsze od tych, o których pisano kilkadziesiąt lat temu (Półtawska, 1981, s. 28-45).

Ważnym antidotum na wymienione negatywne faktory zniekształcające lub wręcz przekreślające relację miłości między mężczyzną i kobietą jest jej wizja ukazana w Pieśni nad pieśniami. Księga ta to biblijny poemat w całości poświęcony tajemnicy miłości, która wydarza się między oblubieńcem i oblubienicą. Obydwie te postaci - on i ona - tworzą parę przeżywającą swą wzajemną miłość jako najwyższe wyzwanie i szczęście zarazem. Ono nadaje najgłębszy sens ich życiu, czyni je pełnym blasku i radości.

Miłość przedstawiona w Pieśni nad pieśniami jest idealna, nie zna zdrady ani najmniejszej niewierności, w przeciwieństwie do miłości małżeńskiej opiewanej w innych księgach biblijnych. Biorąc pod uwagę proces powstawania i podwójnej redakcji Pnp w środowisku sapiencjalnym monarchicznego Izraela (poczynając od czasów Salomona), można postawić tezę, że opiewane w niej doświadczenie wzajemnych więzi łączących oblubieńca i oblubienicę przedstawia głęboko przemyślaną i potwierdzoną $\mathrm{w}$ doświadczeniu kilku generacji wizję miłości, jaka winna łączyć mężczyznę i kobietę. Została ona im zadana w momencie stworzenia. Jakie są najważniejsze aspekty czy nurty tej miłości, do której Bóg powołuje mężczyznę i kobietę? Inaczej mówiąc, czym jest miłość: jak się rodzi?; na czym polega w swej istocie?; co stwarza między mężczyzną i kobietą?; dlaczego daje szczęście?

Miłość oblubieńca i oblubienicy wydarza się na trzech płaszczyznach: oczarowania (zakochania się), erosa i agape. Nakładają się one na siebie i są organicznie ze sobą zintegrowane. Na każdej z nich na pierwszy plan wysuwa się właściwy jej dynamizm i odpowiedzialne zań komponenty cielesno-duchowej osoby oblubieńca i oblubienicy. Odkrywając je, możemy dostrzec to, co może rzeczywiście chronić oblubieńczą i małżeńską miłość w czasach współczesnych przed największymi zagrożeniami. 


\section{MIŁOŚĆ (ZAKOCHANIE) \\ RODZI SIĘ POD WPŁYWEM PIĘKNA: OCZAROWANIE}

Miłość między oblubieńcem i oblubienicą w Pieśni nad pieśniami rodzi się w kontekście nieoczekiwanego odkrycia piękna, które się „objawia i przekonuje bez argumentów" (Schökel, 1993, s. 48-50). W pewnym momencie on zostaje oczarowany i pociągnięty jej pięknem, co wyraża w pieśni zachwytu: „O jak piękna jesteś, przyjaciółko moja, jak piękna, oczy twe jak gołębice!” $(1,15)$. Ona w tym samym czasie odkrywa zachwycające piękno jego postaci: „Zaiste piękny jesteś, miły mój, o jakże czarujący" (wł.: incantevole)! $(1,16)$. Obydwoje w całej Pieśni używają tego samego słownictwa odnoszącego się do ich piękna, a zwłaszcza przymiotnika japa - japeh (,,piękny, uroczy”). Przymiotnik ten rozbrzmiewa osiem razy w Pnp $(4,1.7 ; 5,9 ; 6,1,4.10)$. Odnosi się do tego, co widać, co ma materialny, fizyczny kształt. Abraham, ,gdy się już zbliżał do Egiptu, rzekł do swojej żony, Saraj: «Wiem, że jesteś urodziwą kobietą»" (Rdz 12,11). A o Józefie sprzedanym do Egiptu Księga Rodzaju mówi: „Józef miał piękną postać i miłą powierzchowność" (aparycję, wygląd - Rdz 39,6). Z kolei Dawid w 1 Sm 16,12 jawi się przed prorokiem Samuelem jako chłopiec, który „był rudy, miał piękne oczy i pociągający wygląd”. Rzecz znamienna, że również w Pieśni nad pieśniami oblubieniec wpatruje się w oczy oblubienicy, porównując je do gołębi. Są one w Biblii symbolem wierności, niewinności i delikatności, wrażliwości, serdecznej czułości (wł. tenerezza). Oczy dziewczyny mówią spojrzeniami, swym blaskiem, serdecznością, żarliwością. W swych oczach oblubieniec i oblubienica umieją odczytać „słowa” niewypowiedziane ustami, uczucia niewyrażone i rozpoznać każdy, nawet najmniejszy znak rodzącej się między nimi więzi miłości.

Piękne oczy przyciągają i każą poznawać piękno całej postaci. Pieśń nad pieśniami postrzega postać, inaczej mówiąc - ciało mężczyzny i kobiety, jako formę, w której objawia się dusza, nierozerwalnie i ściśle $\mathrm{z}$ nim złączona. W istocie widoczna dla oczu postać - ciało uobecnia osobę, która jest źródłem wielorakich impulsów i oddziaływań, a zarazem jest ich odbiorcą na zasadzie wzajemności. Ciało ma swój język, który objawia tożsamość osoby i odsłania jej najgłębsze tajemnice. Pieśń nad pieśniami jest jedyną księgą Biblii, która tak obszernie koncentruje uwagę oblubieńca na ciele oblubienicy (i odwrotnie), czyli na ich odrębnej tożsamości osobowej. Daje poznać różne jej meandry i sekrety, a nade wszystko wysławia ich piękno, które przyciąga uwagę, przekonuje, intensyfikuje obecność, oczarowuje, zachwyca - inaczej mówiąc - mocno inspiruje do miłowania, pociąga i kreuje zalążek więzi osobowej. 
Najpierw piękno kobiety (jej postaci) wyraża słowami pieśni mężczyzna:

O jak piękna jesteś, przyjaciółko moja, jakże piękna! Oczy twe jak gołębice za twoją zasłoną. Włosy twe jak stado kóz falujące na górach Gileadu. Zęby twe jak stado owiec strzyżonych, gdy wychodzą z kąpieli: każda z nich ma bliźniaczą, nie brak żadnej. Jak wstążeczka purpury wargi twe i usta twe pełne wdzięku. Jak okrawek granatu skroń twoja za twoją zasłoną. Szyja twoja jak wieża Dawida, warownie zbudowana; tysiąc tarcz na niej zawieszono, wszystką broń walecznych. Piersi twe jak dwoje koźląt, bliźniąt gazeli, co pasą się pośród lilii. Nim wiatr wieczorny powieje i znikną cienie, pójdę ku górze mirry, ku pagórkowi kadzidła. Cała piękna jesteś, przyjaciółko moja, i nie ma w tobie skazy $(4,1-7)$.

W słowach tych pojawia się miłość zmysłowa, ale jest niezwykle delikatna, wolna od jakiejkolwiek wulgarności, presji, egoistycznego pożądania, chęci dominacji, złośliwości czy hipokryzji. Pieśń o ciele oblubienicy jest pełna aluzji. Cały wymiar tożsamości płciowej (seksualność) jest w niej poetycko przywołany, a w przedostatnim wersie jej ciało porównane jest do majestatycznej góry, otoczonej zewsząd zapachami drzew i krzewów balsamowców (mirra) i drzewa sandałowego (kadzidło). W Starym Testamencie mirra była składnikiem oleju świętego, używanego do namaszczania (Wj 30,23.25) (Włodarczyk, 2011). Bardzo znamienne jest to, że całe ciało oblubienicy (postać) oddziałuje poprzez zmysł wzroku na oblubieńca, pociąga go ku sobie i skłania do podjęcia drogi ku tej wspaniałej górze, jaką jest jej osoba w swej cielesno-duchowej konstytucji. Równocześnie jej ciało oddziałuje na jego duszę i skłania go do mówienia, do pełnego harmonii dialogu. Całe jawi mu się jako piękno doskonałe i nietknięte, nieskażone - wręcz przeniknięte jakąś sakralną czystością (w języku ST „czyste” to przynależące do Boga, sakralne), królewskim dostojeństwem. Ewentualne braki czy plamy znikają, ponieważ wszystko oczyszcza ogień miłości, który już zaczął płonąć w jego oczach. Czystość jej ciała jest tak wielka, że oblubieniec w ostatnim wersie wręcz woła: „Cała piękna jesteś, przyjaciółko moja, i nie ma w tobie skazy” (w. 7). Używa słownictwa typowego dla Księgi Kapłańskiej, w której wyrażenie „bez skazy” odnosi się do ofiar, które mogły być składane Bogu, i do osób, które mogły je składać, czyli były „czyste”: mogły być przeniesione $\mathrm{w}$ formie miłej woni w pozamaterialną przestrzeń Boga, a ofiarnicy stawać w Bożej obecności (por. Kpł 21,17.18.21.23; 24,19n). A w 2 Sm 14,25 postać królewicza Absaloma określona jest następująco: „W całym Izraelu nie było człowieka tak pięknego jak Absalom. O nim wygłaszano pochwały: «Od stóp do głowy nie było na nim skazy»". Oblubieniec widzi w oblubienicy piękno doskonale „czyste”, czyli uobecniające wręcz piękno dane przez Stwórcę, i mające w sobie 
coś boskiego i do Boga odsyłające. Tradycja chrześcijańska zaaplikowała określenie „bez skazy” do wspólnoty wierzących chrześcijan zjednoczonych ze zmartwychwstałym Chrystusem (por. Ef 1,4; Kol 1,22; Flp 2,15; Ap 14,5), do samego Chrystusa (por. Hbr 9,14; 1 P 1,19) i do Matki Najświętszej - Maryi jako Oblubienicy Ducha Świętego (Boga) w słynnej antyfonie: Tota pulchra es, Maria, et macula originalis non est in te.

Również Oblubienica odkrywa piękno postaci swego oblubieńca $(5,10-16)$. Na dociekliwe pytanie jerozolimskich dziewcząt: „Jakiż to jest ten twój miły z najmilszych, o najpiękniejsza z niewiast? Jakiż to jest ten twój miły z najmilszych, że nas tak zaklinasz?” (w. 9), odpowiada słowami swej pieśni:

Miły mój śnieżnobiały i rumiany, znakomity spośród tysięcy. Głowa jego najczystsze złoto, kędziory jego włosów jak gałązki palm, czarne jak kruk. Oczy jego jak gołębice nad strumieniami wód. Zęby jego wymyte w mleku spoczywają w swej oprawie. Jego policzki jak balsamiczne grzędy, dające wzrost wonnym ziołom. Jak lilie wargi jego, kapiące mirrą najprzedniejszą. Ręce jego jak walce ze złota, wysadzane drogimi kamieniami. Tors jego rzeźba z kości słoniowej, pokryta szafirami. Jego nogi - kolumny z białego marmuru, wsparte na szczerozłotych podstawach. Postać jego wyniosła jak Liban, wysmukła jak cedry. Usta jego przesłodkie i cały jest pełen powabu. Taki jest miły mój, taki jest przyjaciel mój, córki jerozolimskie! (5,10-16).

Oblubieniec w jej oczach jest ,pierwszym pośród tysięcy innych” (hebr.: dagul - wyjątkowy, pierwszy, lider, wyróżniający się pośród innych). Emanujące z jego postaci piękno czyni go kimś wyjątkowym, jedynym, niepowtarzalnym najardziej zachwycającym pośród niezliczonej liczby innych mężczyzn (hebr. $m^{e}$ rebabah). Jej oblubieniec jest jak chorągiew, jak piękny sztandar powiewający ponad wojskiem złożonym $\mathrm{z}$ tysięcy dzielnych bohaterów; on jest najmocniejszy i najcudowniejszy na świecie. W jej pieśni oblubieniec przypomina Józefa egipskiego (Rdz 39,6), Dawida (1 Sm 16,12; 17,42), Absaloma (2 Sm 14,25; por. także opis najwyższego kapłana Szymona w Syr 50,5-10). W końcowej części pieśni oblubienica mówi o nim jako o kimś młodym, pełnym świeżości i siły - jak wybrane i wspaniałe cedry. Występujący w wersie 15 imiesłów bahur, thumaczony najczęściej jako „wybrany, wspaniały” - czytany w kontekście całej Biblii zawiera aluzję do wyborowych oddziałów wojska, złożonych z młodych, odważnych i wręcz bohaterskich żołnierzy. A w przedostatnim wersie oblubienica stwierdza: „Usta jego przesłodkie i cały jest pełen powabu” (w. 16a). Słodkie „usta” to jego słowa i jego pocałunki. Ich oddziaływanie na nią porównane jest do słodyczy, która przełamuje obojętność, zyskuje sympatię, podbija serce i upaja. Ostatecznie 
oblubienica woła: „On cały jest pełen powabu” (hebr.: we kullo mahmadim cała jego (postać) pełna piękna, godna miłości, budząca miłość, pociągająca (w przekładzie Septuaginty wers 16 brzmi: holos epithymia - cały (jest) pragnieniem, budzi pragnienie, tęsknotę). W Księdze Izajasza $(64,10)$ użyty w wersie 16 hebrajski rzeczownik mahmadim oznacza piękny wystrój świątyni jako przedmiot najgorętszej, świętej miłości: „wszystko, cośmy kochali”). W postaci oblubieńca jest ciepło i słodycz, które potrafią oczarować oblubienicę. Wszystko w nim ją zachwyca. Ma w sobie jakąś tajemniczą, sakralną (jak wnętrze świątyni) siłę, która podbija duszę i ciało oblubienicy, która głosem zachwytu obwieszcza wszystkim wokół siebie: „Taki jest miły mój, taki jest przyjaciel mój, córki jerozolimskie!”. Oblubieniec nie jest kimś wyizolowanym, odseparowanym przez oblubienicę zazdrośnie od innych.

Piękno nie tylko objawia jakąś pierwotną (ze stworzenia) i sakralną tajemnicę pociągającą mężczyznę ku kobiecie i kobietę ku mężczyźnie, ale wyzwala i rozbudza $\mathrm{w}$ nich napięcie seksualne, pożądanie. Zrodzone w nich za sprawą dojrzanego piękna wzajemna miłość i oczarowanie (zakochanie się) pozwala to napięcie widzieć znacznie szerzej i głębiej niż jako czynnik biologiczno-psychiczny. Szerzej, bo ciało (cała osoba: ciało objawiające ducha) oblubieńca czy oblubienicy rozkwita, „powiększa się" i jaśnieje za sprawą tej rodzącej się miłości. Wyraża to w Pnp obraz wiosny, która otacza i napełnia swym czarem wszystkie sytuacje, ale także inne obrazy, na przykład dalekiej, wzniosłej jutrzenki. A doskonałą syntezą tych wszystkich pejzaży wiosennych i astralnych jest ogród, podobny do rajskiego, w którym wszystko się odbija i promieniuje: „Ogrodem zamkniętym jesteś, siostro ma, oblubienico, ogrodem zamkniętym, źródłem zapieczętowanym” (4,12; por. ww. 15-16; 5,1; 6,2-11; 8,12 - winnica). Nad tym ogrodem, którym w Pieśni nad pieśniami jest ciało oblubienicy, świeci słońce i księżyc, tak że cała postać oblubienicy staje się promienna: „Kimże jest ta, która świeci z wysoka jak zorza, piękna jak księżyc, jaśniejąca jak słońce, groźna jak zbrojne zastępy?” $(6,10)$. Następują po sobie poranki ze światłem jutrzenki i noce ze światłem księżyca: „Jam miłego mego i ku mnie zwraca się jego pożądanie. Pójdź, mój miły, powędrujemy w pola, nocujmy po wioskach! O świcie pospieszmy do winnic, zobaczyć, czy kwitnie winorośl” (7,11-13). Użyty w wersie 13 hebrajski rzeczownik teszukah jest bardzo znaczący w swej wymowie; oznacza ,namiętność” „pożądanie”, ,popęd” (Luzarraga, 2005, s. 540-547). A światło wiosny, które wszystko przenika, przemienia oblubienicę i oblubieńca w postaci piękne, wręcz promienne, promieniujące pięknem i tym bardziej wzajemnie pożądane. Oblubienica świadomie potwierdza, że nie tylko kocha swego umiłowanego, ale także że jest kochana, pożądana, oczekiwana przez niego. 
Używając tego rzeczownika (teszukah) autor Pnp odsyła do Księgi Rodzaju, ale nie do opisu grzechu pierworodnego. Paralelą jest sytuacja sprzed upadku: opis napięcia seksualnego, jakie istnieje w relacji mężczyzny i kobiety: „«Ta dopiero jest kością z moich kości i ciałem z mego ciała! Ta będzie się zwała niewiastą, bo ta z mężczyzny została wzięta»" (2,23; por. 4,7). Mowa tu o napięciu seksualnym i pozytywnym etycznie pożądaniu (Barbiero, 2011, s. 403-405).

Pieśń nad pieśniami - jak wynika z przytoczonych tekstów - głosi pochwałę namiętności, samego popędu seksualnego, pożądania, ponieważ wywołany jest on przez autentyczne piękno, i nade wszystko karmi się zaczynem miłości. Opiewa równość dwóch osób, mężczyzny i kobiety, pewność ich wzajemnego wzruszenia, podobnego oddziaływania na te same zmysły (Ravasi, 2005, s. 122). „Pożądanie" - przedstawione szerzej w Rdz 2,23 i 4,7, czy - inaczej mówiąc - namiętność (miłość zmysłowa) traci wszelki ślad egoizmu po obydwu stronach, wyraża czystą wolę pełnego objawienia swego piękna i poznania pełnego piękna osoby umiłowanej. Płynąca z tak przeżywanego pożądania czy namiętności radość nie pozostaje ślepa, zazdrośnie zamknięta dla siebie, ale otwarta i udzielająca się: „Taki jest miły mój, taki jest przyjaciel mój, córki jerozolimskie!”.

Jak widać z przytoczonych tekstów miłość rodzi się na podłożu popędu seksualnego. W bezpośrednim zetknięciu się mężczyzny i kobiety zawsze zachodzi jakieś wrażenie zmysłowe, do którego często dołącza się wzruszenie, gdyż reprezentują oni dla siebie wzajemnie pewną wartość. Wzruszenie może być także spowodowane wartościami duchowymi, jednak zazwyczaj w przypadku bezpośredniego spotkania kobiety i mężczyzny przeważa wzruszenie wartościami podpadającymi pod zmysły. Można mówić o przeżyciu piękna, np. piękna ciała. Piękno to wywołuje w człowieku radość, przyciąga. Budząc się pod wpływem wartości seksualnej drugiej osoby, miłość zmysłowa zawiera w sobie pożądanie, które, gdy nie jest poddane kontroli umysłu, w zasadzie przeszkadza w przeżywaniu piękna kobiety czy mężczyzny. Zwłaszcza ciało kobiety dla zmysłowości mężczyzny jawi się przede wszystkim ,jako pożądane”. Pieśń nad pieśniami mówi, że oblubieniec widzi w jej ciele „coś” więcej - widzi całe bogactwo cielesno-duchowe, czyli ostatecznie jej osobę, na co wskazują liczne, poetyckie odniesienia do różnych części ziemi obiecanej.

Ponieważ reakcja zmysłów mężczyzny czy kobiety jest spontaniczna, odruchowa, nie można mówić, że jest moralnie zła, jest poniekąd naturalna. Zmysłowość ta jest tworzywem ich oblubieńczej miłości, która po pewnym czasie stanie się wręcz więzią miłości małżeńskiej. Miłość - zakochanie się, będąca w istocie oczarowaniem, rodzi się przez zmysły zewnętrzne, np. głównie przez wzrok i słuch, ale także przez wyobraźnię i pamięć. 


\section{MIŁOŚĆ EROTYCZNA \\ - WZAJEMNE SZUKANIE INTYMNEJ BLISKOŚCI}

Miłość oblubieńca i oblubienicy - na drugim poziomie - wyraża się przez emocjonalne przeżywanie kobiecości (wraz z jej wdziękiem, powabem) i męskości (wywołującej wrażenie siły) - jak zostały one ukazane w obydwu analizowanych powyżej pieśniach o ciele. Na czym te emocje polegają: jakie one są?

\subsection{UPOJENIE CIELESNĄ RÓŻNORODNOŚCIĄ I BOGACTWEM DARÓW DUCHOWYCH}

Pierwszym uczuciem jest bez wątpienia uniesienie. Jednym z fragmentów, które bodaj najbardziej obrazowo ukazują, jak oblubieniec emocjonalnie przeżywa kobiecość oblubienicy, jest pieśń opiewająca jej taniec. Jest to uczucie zachwytu ciałem i objawiającymi się w kunszcie tego tańca zdolnościami, wrażliwością i pragnieniami duszy oblubienicy. Tańcząc dla swego umiłowanego, ofiaruje mu „coś więcej” niż swe wirujące ciało - swą kobiecą, królewską wręcz wielkość i godność:

Obróć się, obróć, Szulamitko, obróć się, obróć się, niech się twym widokiem nacieszymy! Cóż się wam podoba w Szulamitce, w tańcu obozów? Jak piękne są twe stopy w sandałach, księżniczko! Linia twych bioder jak kolia, dzieło rąk mistrza. Łono twe, czasza okrągła: niechaj nie zbraknie w niej wina korzennego! Brzuch twój jak stos pszenicznego ziarna okolony wiankiem lilii. Piersi twe jak dwoje koźląt, bliźniąt gazeli. Szyja twa jak wieża ze słoniowej kości. Oczy twe jak sadzawki w Cheszbonie, u bramy Bat-Rabbim.

Nos twój jak baszta Libanu, spoglądająca ku Damaszkowi. Głowa twa wznosi się nad tobą jak Karmel, włosy głowy twej jak królewska purpura, splecione w warkocze. O jak piękna jesteś, jakże wdzięczna (dosł.: pełna czaru, cudowna, umiłowana, pełna rozkoszy)! $(7,7)$

W tak bogatej odmienności, w harmonijnym pięknie wszystkich części jej ciała skupia się jak w soczewce połowa świata przyrody i świata natury. Oblubieniec wyraża swe upojenie tą odmiennością - objawia swe przeżycia na poziomie erosa. Ona - dotychczas mu nieznana i niedostępna - budzi w nim wołanie, które wyraża pragnienie posiadania jej (miłość posesywna, pragnienie bycia blisko - eros): „Z Libanu przyjdź, oblubienico, z Libanu przyjdź i zbliż się! Zstap ze szczytu Amany, z wierzchołka Seniru i Hermonu, z jaskiń lwów, z gór lampartów” $(4,7)$. Cała jego osoba przeniknięta jest jej „promieniującą" w tańcu miłością - upodobaniem i pragnieniem nasycenia się jej dynamiczną, 
a jakże upajającą miłosną obecnością, nawet jeżeli ona wydaje się być tak niedostępna jak „szczyt Amany, wierzchołki Seniru i Hermonu,”, jak jaskinie lwów i urwiste góry lampartów. Piękno jej tańca wykonywanego tylko dla niego nie tylko oczarowuje serce, ale upaja całe wnętrze (duszę) jak wino, jak zapach najlepszych olejków pachnących: „Oczarowałaś me serce jednym spojrzeniem twych oczu, jednym paciorkiem twych naszyjników. Jak piękna jest miłość twoja, siostro ma, oblubienico, o ileż słodsza jest miłość twoja od wina, a zapach olejków twych nad wszystkie balsamy!" (4,9-10). To doświadczenie jej bogatej tożsamości płciowej (kobiecości), różnej od jego własnej, nie tylko go upaja, ale wręcz przenika jego duszę i napełnia ją tą jej kobiecą tożsamością, miłującą go obecnością - tak jak smak najlepszego wina, jak zapach mocniejszy od balsamów na długo pozostaje w człowieku (Alonso Schökel, 1993, s. 58-59).

W pewnym momencie oddziaływanie na niego całej jej postaci, jej ciała wyrażającego duszę (spojrzenie oczu; słodycz i zapach) budzi w nim niepokój i wyzwala postawę obronną:

Piękna jesteś, przyjaciółko moja, jak Tirsa, wdzięczna jak Jeruzalem, groźna jak zbrojne zastępy. Odwróć ode mnie twe oczy, bo niepokoją mnie. Włosy twoje jak stado kóz falujące na górach Gileadu. Zęby twoje jak stado owiec wychodzących z kąpieli, każda z nich ma bliźniaczą, nie brak żadnej. Jak okrawek granatu skroń twoja, za twoją zasłoną" $(6,1-7)$

Początkowa relacja polegająca na miłości zmysłowej, na popędzie seksualnym, na pożądaniu wywołanym przez dostrzeżone piękno płci, zostaje ubogacona i pogłębiona doświadczeniem upojenia jej zupełnie wyjątkowym, cielesno-duchowym pięknem i bogactwem zarazem, które jest pilnie strzeżone jak przywołane tu obydwie stolice: Tirsa i Jerozolima. W przestrzeń miłości zmysłowej wkracza eros (łac. amor), który zawiera $\mathrm{w}$ sobie dynamizm zdobywania połączony z pragnieniem przebywania wewnątrz tej wspaniałej przestrzeni cielesno-duchowej osoby umiłowanej (porównanej tu do wspaniałych miast, w innym miejscu do rozkosznego ogrodu). Jest to zarazem pragnienie coraz większej pełni, dążenie do tego, by umiłowanej dostarczać jak największej ilości przyjemności, w tym także błogości, uniesienia, rozkoszy i spełnienia w sferze płciowości (Bloch, 2006, s. 207).

Umiłowana i umiłowany w przestrzeni miłości erotycznej stają się nawzajem dla siebie wyzwaniem, bo on jawi się jako jedyny, a ona jako jedyna na świecie. Ona w swej kobiecości staje się dla niego najpiękniejszą, wybraną, najważniejszą na świecie - jaśniejącą i promieniejącą w niepowtarzalny sposób jak słońce. Ona jako kobieta staje się - w sensie osobowym - słońcem jego dni i księżycem jego nocy: 
Sześćdziesiąt jest królowych i nałożnic osiemdziesiąt, a dziewcząt bez liczby, jedyna jest moja gołąbka, moja nieskalana, jedyna swej matki, wybrana swej rodzicielki. Podziwiają ją dziewczęta i zwą ją szczęśliwą, królowe i nałożnice ją wysławiają: «Kimże jest ta, która świeci z wysoka jak zorza, piękna jak księżyc, jaśniejąca jak słońce, groźna jak zbrojne zastępy?» (6,8-10)

Przekład „jaśniejąca” (,pełna światła” - wł.: luminosa; Alonso Schökel 1993, s. 51-53 nie oddaje całego bogactwa rzeczownika hebrajskiego bar. Zawiera on w sobie też odniesienie do żaru słońca, do czystości i świetlistości jego promieni (por. Hi 11,4; Ps 19,9; 24,4; 73,1).

Podobne uczucie oczarowania cielesno-duchowym pięknem oblubieńca (jego wyjątkową męskością) przeżywa oblubienica. Daje temu wyraz kilka razy, ale bodaj najmocniej w słynnej pieśni, w której porównuje jego postać do świątyni, pełnej wspaniałych kolumn i zdobień:

Miły mój śnieżnobiały i rumiany, znakomity spośród tysięcy. Głowa jego najczystsze złoto, kędziory jego włosów jak gałązki palm, czarne jak kruk. Oczy jego jak gołębice nad strumieniami wód. Zęby jego wymyte w mleku spoczywają w swej oprawie. Jego policzki jak balsamiczne grzędy, dające wzrost wonnym ziołom. Jak lilie wargi jego, kapiące mirrą najprzedniejszą. Ręce jego jak walce ze złota, wysadzane drogimi kamieniami. Tors jego rzeźba z kości słoniowej, pokryta szafirami. Jego nogi - kolumny z białego marmuru, wsparte na szczerozłotych podstawach. Postać jego wyniosła jak Liban, wysmukła jak cedry. Usta jego przesłodkie i cały jest pełen powabu. Taki jest miły mój, taki jest przyjaciel mój, córki jerozolimskie! (5,10-16)

Eros wyraźnie obecny w relacji oblubieńca i oblubienicy z Pieśni nad pieśniami oznacza $w$ gruncie rzeczy zachwyt i upojenie wyjątkowym i jedynym na świecie bogactwem ich osób, estetyką ciał, harmonią poszczególnych części, w której de facto odbija się nie tylko harmonia przywoływanej często natury i przyrody, wręcz całego stworzenia, ale tajemnicza i święta obecność Stwórcy podobna do świetlistej chwały wypełniającej w momencie teofanii jerozolimską świątynię. Tak piękny i bogaty wewnętrznie oblubieniec jest pełen powabu - ku niemu zwraca się też jej miłość, którą określa się mianem erosa. Chciałaby się i ona znaleźć wewnątrz tej wspaniałej świątyni jego ciała, upojona jej sakralnym powabem.

Odkrywany tu dynamizm zdobywania, pragnienie posiadania osoby umiłowanej, doskonale widoczny jest również w pieśni z rozdziału 7, w którym oblubieniec mówi do umiłowanej: 
Postać twoja wysmukła jak palma, a piersi twe jak grona winne. Rzekłem: wespnę się na palmę, pochwycę gałązki jej owocem brzemienne. Tak! Piersi twe niech mi będą jako grona winne, a tchnienie twe jak zapach jabłek. Usta twoje jak wino wyborne, które spływa mi po podniebieniu, zwilżając wargi i zęby (ww. 8-10)

Oblubienica jest jedyna w swoim rodzaju. Tylko ona może nasycić wszelkie pragnienia bliskości i wspólnoty, jakie narastają w duszy jej ukochanego mężczyzny, który jednak musi ją nieustannie zdobywać i o nią walczyć siłą swej miłości (Barbiero, 2011, s. 394-395).

Miłość erotyczna nie kończy się w Pnp na zdobywaniu osoby umiłowanej. Ona wywyższa i unosi w stronę nieba. Mówią o tym ostatnie wersety rozdz. 6:

Zszedłem do ogrodu orzechów, by spojrzeć na świeżą zieleń doliny, by zobaczyć, czy rozkwita krzew winny, czy w kwieciu są już granaty. Nie wiedząc o tym, moje pragnienie uczyniło mnie jak wozy Aminadaba (ww. 11-12)

Występujący w ostatnim zdaniu hebrajski rzeczownik nefesz oznacza „duszę”, ale także „oddech”, ,pragnienie” całej istoty ku czemuś ukochanemu i upragnionemu. Poeta mówi zatem, że oblubieniec niemal nieświadomie niesiony żarem swej miłości uczuciowej rzucił się w pewnego rodzaju szalony bieg, jak na rydwanach księcia Aminadaba, będącego aluzją do egipskiego księcia, który jeździł na bardzo szybkich rydwanach, stale szukając najpiękniejszych dziewcząt. Miłość przeżywana przez oblubieńca w ogrodzie wspaniałości, jakim jest cielesno-duchowa rzeczywistość jego kobiety, porywa go i unosi do nieba w ekstazie, tak jak zdarzyło się to Eliaszowi na rydwanie ognistym (2 Krl 1-2). Miłość, która jest w niej obecna, jest podobna do owych ognistych rumaków unoszących rydwan Eliasza ku niebu (Barbiero, 2011, s. 355-361). Przywołane wcześniej symbole winnego krzewu i drzewa granatu dopowiadają, że oblubieniec upojony pięknem swej kobiety otrzyma od niej aromatyczne wino, które podnieca i oszałamia, i niezwykle słodki sok granatu, który upaja i tak samo, podnieca - jest także symbolem płodności i gwarantuje długowieczność.

\subsection{TĘSKNOTA I „SZUKANIE”}

Wzajemne oczarowanie - męskością i kobiecością - rodzi w ich duszach tęsknotę wówczas, gdy są oddaleni od siebie. Dlatego podejmują wzajemne szukanie, inspirowane tym silnym uczuciem tęsknoty za sobą i pragnieniem intymnej bliskości. Pojawia się ono w wielu miejscach Pieśni nad pieśniami. Nie ma jedy- 
nie charakteru incydentalnego, początkowego, ale jest ono stałe, kontynuowane na różnych etapach wspólnej historii. Już na początku poematu stęskniona za umiłowanym oblubienica woła: „O ty, którego miłuje dusza moja, wskaż mi, gdzie pasiesz swe stada, gdzie dajesz im spocząć w południe, abym się nie błąkała wśród stad twych towarzyszy" $(1,7)$. Momentami to szukanie staje się dramatyczne. Słyszymy w przytoczonym wersecie jej słodki głos, który zarazem jest pełen goryczy z powodu jego oddalenia się: „Ty, którego miłuje dusza moja”. Rzeczownik dusza (nefesz) wyraźnie łączy duchowe pragnienie z oddechem, czyli z samym jej istnieniem. Oblubieniec jest dla zakochanej w nim kobiety jak oddech, więcej - jest jej oddechem, czyli jej życiem. Jego nieobecność grozi śmiercią, destrukcją jej własnego ,ja”. Im dłuższa jego nieobecność, tym ona bardziej intensywnie go szuka, ogarnięta bezbrzeżną tęsknotą:

Na łożu mym nocą szukałam (hebr.: biqqaszti) umiłowanego mej duszy, szukałam go, lecz nie znalazłam. «Wstanę, po mieście chodzić będę, wśród ulic i placów, szukać będę ukochanego mej duszy». Szukałam go, lecz nie znalazłam. Spotkali mnie strażnicy, którzy obchodzą miasto. «Czyście widzieli miłego duszy mej?» $(3,1-3)$

Oblubienica szuka tego, którego miłuje jej dusza, nie bacząc na ciemność nocy, ani na grożące niebezpieczeństwa czy szyderstwa.

Również oblubieniec szuka swej umiłowanej. W pewnym momencie to ona dostrzega jego pełne trudu szukanie i dążenie na spotkanie z nią: „Cicho! Ukochany mój! Oto on! Oto nadchodzi! Biegnie przez góry, skacze po pagórkach” $(2,8)$. Ukochany - odpowiadając na początkowe poszukiwanie miejsca, gdzie pasie swe stada, na jej pełne tęsknoty oczekiwanie - przybywa do jej domu. Minęła długa noc oddalenia, milczenia i oczekiwania. I oto on przybliża się, a jego szukanie koncentruje się na jej twarzy i głosie: „Gołąbko ma, ukryta w zagłębieniach skały, w szczelinach przepaści, ukaż mi swą twarz, daj mi usłyszeć swój głos! Bo słodki jest głos twój i twarz pełna wdzięku" $(2,14)$. Oblubienica porównana do gołąbki ukrytej w tajemniczej szczelinie skalnej nad przepaścią jest niedostępna dla niego. Oboje pozostają jakby na dwóch górach, bliskich sobie, a jednak oddzielonych przepaścią. Stąd jego żarliwe wołanie - prośba: „ukaż mi swą twarz, daj mi usłyszeć swój głos!”. To jego jedyne oczekiwanie, jedyne pragnienie. To pragnienie propozycja - więzi tak silnej i bliskiej, że znosi ona separację, oddalenie, nieobecność i tajemnice. Jednak na tym etapie pozostają względem siebie w tajemniczym oddaleniu, symbolizowanym przez górską przepaść. Oblubieniec woła, aby ta, która jest niedostępna, stała się bliska (Alonso Schökel, 1993, s. 68-69). 
Eros w Pnp to uczuciowość, która wyraża się poprzez czułość. Nie jest ona konsumpcyjna, wydaje się być wolna od pożądania w tym znaczeniu co zmysłowość. Jest w niej natomiast pragnienie bliskości i zbliżenia na poziomie przeżyć i emocji, a równocześnie wyłączności i intymności. Na tym poziomie często dochodzi do idealizacji drugiej osoby. Silne emocje związane z umiłowaną osobą każą „wkładać” w jej postać wiele wartości, których ona sama w sobie nie musi koniecznie posiadać. Najczęściej braki te dobrze widzą inni. Wychowywanie do szczęśliwej miłości winno na to zwracać szczególną uwagę.

\section{MIŁOŚĆ OFIARNA - JEDNOCZĄCA W CIELESNO-DUCHOWEJ KOMUNII I PRZEMIENIAJĄCA OBLUBIEŃCA I OBLUBIENICĘ}

Miłość - obudzona przez piękno i wzrastająca za sprawą emocji na drodze szukania wzajemnej obecności - dąży do intymnej więzi osobowej, w której jednoczą się dwa całkiem odrębne dotychczas podmioty cielesno-duchowe: „ja” i „ty”, oraz to, co jest „moje i twoje”. Równocześnie dokonuje się ich radykalna przemiana, o której mówią trzy strofy w rozdziale ósmym (ww. 5b.6.7).

\subsection{ZJEDNOCZENIE CIELESNO-DUCHOWE} W PRZESTRZENI WOLNOŚCI

Najbardziej wymownym wyrazem tej osobowej więzi, która wyraża się w zjednoczeniu osób, są w Pieśni nad pieśniami słowa: „Mój miły jest mój, a ja jestem jego" $(2,16)$. W przekładzie Septuaginty użyty jest rzeczownik ho adelfos mou („brat mój”, ale także „miły”, „umiłowany”). Fraza ta powtarza się jeszcze dwa razy w tekście Pieśni nad pieśniami. A obraz tej ostatecznej więzi poeta rysuje już $\mathrm{w}$ formie zapowiedzi w rozdziale drugim, gdy oblubienica wyznaje:

Wprowadził mnie do domu wina, i sztandarem jego nade mną jest miłość. Posilcie mnie plackami z rodzynek, wzmocnijcie mnie jabłkami, bo chora jestem z miłości. Lewa jego ręka pod głową moją, a prawica jego obejmuje mnie. Zaklinam was, córki jerozolimskie, na gazele, na łanie pól: nie budźcie ze snu, nie rozbudzajcie ukochanej, póki nie zechce sama $(2,4-7)$

Do wizji tej osobowej, cielesno-duchowej więzi oblubieńca i oblubienicy poeta powraca w rozdziale trzecim $(3,5)$. Ale swoje urzeczywistnienie i zwieńczenie ma ona wówczas, gdy oboje są w objęciach: oblubieniec ukojony w ekstazie 
miłości, a oblubienica, która mówi o tym zjednoczeniu, jakby opowiadała swój cudowny sen:

Lewa jego ręka pod głową moją, a prawica jego obejmuje mnie. Zaklinam was, córki jerozolimskie, na cóż budzić ze snu, na cóż rozbudzać umiłowaną, póki nie zechce sama? $(8,3-4)$

W tych trzech tekstach tak bardzo „cielesnych” wyjątkowo mocno podkreślone są zaimki osobowe. „Miłość bowiem jest relacją, która jednoczy dwie osoby” (Alonso Schökel, s. 79). Ekstaza zjednoczenia mówi coś bardzo ważnego o miłości ofiarnej, w której obydwie osoby ofiarują się sobie nieodwracalnie i jako jedyne. Jest ona „wtargnięciem historii w wieczność i [to] otwarcie się wieczności na historię" (Ravasi, 2005, s. 127). A to dlatego, że miłość ofiarna myśli o szczęściu osoby umiłowanej, pełna jest poświęcenia, troski i odpowiedzialności. Wyraża się poprzez całkowity - wzajemny - dar z siebie, przeżywany jako zjednoczenie ciał i dusz, czyli osób.

Fundamentalnym warunkiem osobowego zjednoczenia oblubieńca i oblubienicy jest wolność. Tę podstawową prawdę Pieśń nad pieśniami wyraża w formie trzy razy wypowiadanego „zaklęcia”, adresowanego do „córek jerozolimskich”: „Na cóż budzić ze snu, na cóż rozbudzać umiłowaną, póki nie zechce sama?”. Występuje ono już w drugim rozdziale: „Nie budźcie ze snu, nie rozbudzajcie ukochanej, póki nie zechce sama" (w. 7; 3,5). Słowa te mają ogromny ciężar gatunkowy. To nie ciało i zmysły są zasadniczą treścią miłości, jest ona zawsze jakąś sprawą wnętrza i ducha. Wolna wola oblubienicy i oblubieńca, który powstrzymuje siebie i innych od jakiegokolwiek wpływu na decyzje oblubienicy (,dopóki nie zechce sama”), jest tą „ostatnią instancją”, bez której miłość nie ma w sobie pełnej osobowej wartości. Miłość potrzebuje wolności, ta zaś możliwa jest jedynie dzięki prawdzie. Pożądanie zmysłowe oraz zaangażowanie uczuciowe mają swoją wewnętrzną prawdziwość. Jest to jednak prawda subiektywna, zależna od danej osoby doświadczającej doznań i uczuć (Wojtyła, 2001, 92-106). Jest ona oczywiście potrzebna. Ale miłość wymaga także prawdy obiektywnej. Prawda obiektywna domaga się przede wszystkim rozpoznania i afirmacji wartości osoby. Wartość ta jest różna względem wartości wrodzonych lub nabytych, które tkwią w osobie, jak np. jej zdolności, cechy charakteru, piękno fizyczne itp. Różni się też od wartości seksualnej, gdyż płeć jest tylko właściwością osoby, a nie całą osobą. Tak rozumiana wartość osoby jest uprzednia wobec wszystkich innych jej wartości. Uczucie - skupiające się tak mocno wokół „kobiecości” i „męskości” - jeśli nie jest 
zintegrowane z afirmacją osoby, może się z czasem wyczerpać w świadomości emocjonalnej tak mężczyzny, jak i kobiety” (Wojtyła, 201, 109-111).

\subsection{MIŁOŚĆ PRZEMIENIAJĄCA OBLUBIEŃCA I OBLUBIENICĘ W MĘŻA I ŻONĘ}

Miłość ofiarna przeżywana jako komunia cielesno-duchowa nie tylko zanurza historię $\mathrm{w}$ wieczności, a wieczność $\mathrm{w}$ historii, ale także przemienia oblubieńca i oblubienicę w męża i żonę. Mówią o tym trzy strofy ostatniej pieśni oblubienicy, zwanej pieśnią miłości ( $8,5 b-7)$ :

Pierwsza strofa, którą można zatytułować „Pod jabłonią”, brzmi następująco: „Pod jabłonią obudziłam cię; tam poczęła cię matka twoja, tam poczęła cię ta, co cię zrodziła"(w. 5b). W jej centrum jest jabłoń, drzewo miłości, opisywane już w 2,3: „Jak jabłoń wśród drzew leśnych, tak ukochany mój wśród młodzieńców. W upragnionym jego cieniu usiadłam, a owoc jego słodki memu podniebieniu". Oblubieniec zasnął w cieniu miłości, której doznał. Teraz oblubienica budzi go swoją czułością i spostrzega, że w tym momencie jest dla swego mężczyzny nie tylko małżonką i „siostrą”, ale także matką. Sens tej sceny jest taki: umiłowany jest w pełni mężczyzną i osobą nie tylko dlatego, że jakaś matka go urodziła, lecz także dlatego, że jest jego małżonka, która go w jakiś sposób zrodziła do nowego życia. Miejsce ich miłości ofiarnej i otwartej na płodność (,pod jabłonią") duchowo pokrywa się z miejscem jego narodzin („tam poczęła cię twoja matka”). Teraz małżonka mówi: „Ja moją miłością budzę cię do nowych narodzin”. Masz szansę narodzić się już nie jako mały chłopiec, ale jako małżonek - ojciec.

Druga strofa, której można nadać tytuł „Jak pieczęć”, brzmi następująco: „Połóż mię jak pieczęć na twoim sercu, jak pieczęć na twoim ramieniu; zaiste, jak śmierć potężna jest miłość, a zazdrość jej nieprzejednana jak Szeol, żar jej to żar ognia, płomień Pański” (w. 6). Ofiarna miłość oblubienicy jest wyłącznie i całkowicie ukierunkowana na jej oblubieńca - małżonka. Poeta używa symbolu pieczęci, aby wyrazić jej pełne oddanie, które przypieczętowuje miłość (ich komunię osobową: bliskość i jedność) na zawsze. Pieczęć służyła do potwierdzania autentyczności dokumentów (por. Wj 28,11) i poświadczania swej własnej tożsamości. Była noszona przez właściciela na palcu lub na ręce razem z bransoletą (por. Rdz 41,42; Jr 22,24). Obraz ten odsyła do pary małżonków w objęciach. Pieczęć mogła być też przywiązana do łańcuszka i zawieszona na szyi (por. Rdz 38,18; Prz 3,3). Opadała na serce, będące znakiem świadomości i sumienia osoby, jej decyzji. Krótko mówiąc, pieczęć jako nierozłączna, przylegająca, dotykająca 
skóry, zazdrośnie strzeżona i broniona rzecz, potwierdzała autentyczność, jednoczyła (por. Hi 41,7), określała osobę i jej tożsamość (Jr 22,24).

Oblubienica położona jak pieczęć na sercu i na ramieniu jest zatem samym „ja” oblubieńca, jest jego „dowodem tożsamości”, jego osobą, „tym samym ciałem”. Śpiewając tę pieśn o sobie jako „pieczęci”, oblubienica chce, aby rozum, wola, uczuciowość, działanie, cała osobowość jednego podmiotu przeszczepiły się, złączyły, sczepiły się z drugim w pełnej symbiozie. Apostoł Paweł, mówiąc o swoim doświadczeniu miłości ofiarnej do Chrystusa, wołał: „Teraz zaś już nie ja żyję, lecz żyje we mnie Chrystus" (Ga 2,20).

Tak silna wzajemna przynależność i komunia osobowa nie może zostać złamana nawet przez najsilniejszego przeciwnika, arcy-wroga każdego człowieka, jakim jest śmierć. Miłość jednocząca dwie osoby jest silniejsza: ,zaiste, jak śmierć potężna jest miłość, a zazdrość jej nieprzejednana jak Szeol, żar jej to żar ognia, płomień Pański” (w. 6). Miłość ze swą żarliwą i wyłączną namiętnością (przywoływaną tu jako „zazdrość” o osobę umiłowaną, o jej przynależność) potrafi przeżyć w zmaganiu ze swym wrogiem - śmiercią (por. Prz 30,15: obydwie naprzeciw siebie jako wrogowie w boju). Płomienie miłości są „płomieniami Jahwe”, czyli są ,płomieniami boskimi”" (stopień najwyższy - por. Ps 36,7; 80,11; 104,16): są najwyższym i niepokonanym płomieniem, podobnym do tego wydobywającego się z krzewu u stóp Góry Bożej - Horebu (por. ogień z nieba w 2 Krl1,12). W tym jedynym tekście Pnp, w którym wspomina się święte imię Boga, bez wątpienia należy dostrzec odniesienie do miłości ludzkiej i do miłości Bożej. Miłość łącząca w komunii osobowej małżonków w jakiś sposób ma udział w miłości i mocy samego Boga, który jest żyjący i daje życie. Podobnie miłość małżonków, dając życie, ostatecznie jawi się jako zwycięska w starciu ze śmiercią. Można stwierdzić, że oblubienica w drugiej strofie swej pieśni wyznaje, że miłość ofiarna, która ją nierozerwalnie jednoczy z oblubieńcem-małżonkiem, w gruncie rzeczy nadaje im - już jako małżonkom - nową, ożywiającą i „,boską” tożsamość: obydwoje stają się źródłem życia i w tym są „obrazem i podobieństwem Boga” (por. Rdz 1,26-28).

Trzecia strofa może nosić tytuł: „Wielkie wody” (w. 7) i brzmi następująco: "Wody wielkie nie zdołają ugasić miłości, nie zatopią jej rzeki. Jeśliby kto oddał za miłość całe bogactwo swego domu, pogardzą nim tylko". Metafora ,wielkie wody” występuje w Starym Testamencie aż 28 razy. Odnosi się do pierwotnych wód otchłani, wód chaotycznych żywiołów czy niszczących wód potopu (por. Rdz 1,2; rozdz. 6-8). W Psalmach jest symbolem śmierci (por. Ps 18,4-5.16; Jn 2,3nn). A autor Ps 69,2-3 woła do Boga: „Wybaw mnie, Boże, bo woda mi sięga po szyję. Ugrzęzłem w mule topieli i nie mam nigdzie oparcia, trafiłem na wodną głębinę 
i nurt wody mnie porywa”. W księgach prorockich „,wielkie wody” (rzeki Nil i Eufrat) oznaczają straszliwe potęgi wojskowe (por. Iz 8,6-8), które zagrażają wszystkiemu, co żyje w Izraelu (por. Iz 17,13; 43,16; Jr 46,7-8; 51,55; Hi 38,8-11).

Jednak oblubienica jest pewna, że łącząca ją z oblubieńcem miłość ofiarna jest w stanie stawić opór każdemu przeciwnikowi. Ona jest jak skała, o którą musi się rozbić rozszalała woda morza czy wezbranych rzek (por. Ps 46). Trudne wypadki historii, minione i przyszłe, codzienne zagrożenia i pojedyncze nieszczęścia nigdy nie będą w stanie oderwać oblubienicy - małżonki od jej ukochanego - męża. Razem, zjednoczeni w komunii osobowej przejdą wszystkie cierpienia, kryzysy, opuszczenia, zachowując nienaruszony płomień ich miłości. Światłość tego ognia nie zna zachodu ani ciemności.

Bez wątpienia o takiej zwycięskiej miłości ofiarnej, łączącej apostoła z Chrystusem, pisał św. Paweł, gdy postawił retoryczne pytanie w Liście do Rzymian: „Któż nas może odłączyć od miłości Chrystusowej? Utrapienie, ucisk czy prześladowanie, głód czy nagość, niebezpieczeństwo czy miecz?” (8,35-36). I odpowiadał, jakby komentując Pnp 8,7:

We wszystkim tym odnosimy pełne zwycięstwo dzięki Temu, który nas umiłował. I jestem pewien, że ani śmierć, ani życie, ani aniołowie, ani Zwierzchności, ani rzeczy teraźniejsze, ani przyszłe, ani Moce, ani co wysokie, ani co głębokie, ani jakiekolwiek inne stworzenie nie zdoła nas odłączyć od miłości Boga, która jest w Chrystusie Jezusie, Panu naszym (ww. 37-39)

\section{IMPLIKACJE PSYCHOLOGICZNO-PEDAGOGICZNE}

Przeprowadzona analiza filologiczno-literacka Pieśni nad pieśniami pod kątem zawartej w niej wizji miłości mężczyzny i kobiety pozwala na wyprowadzenie kilku wniosków natury psychologiczno-pedagogicznej. Ich aplikacja w procesie wychowania może stanowić ważne antidotum na współczesne zagrożenia tej podstawowej więzi międzyludzkiej.

1. W Pieśni nad pieśniami ukazana jest miłość w trzech, następujących po sobie, a zarazem kolejno dopełniających się fazach: miłość jako zakochanie się (oczarowanie), miłość uczuciowa (eros) i miłość ofiarna (agape). Dwie pierwsze to w istocie swej miłość oblubieńcza, wolna od współżycia seksualnego. Ale ostatecznie osiąga ona szczyt w postaci miłości matżeńskiej, którą otwiera cielesno-duchowe zjednoczenie oblubieńca i oblubienicy. Zachowanie tej kolejności, intensywne przeżywanie każdego z tych etapów to podstawowy wniosek - reguła 
idealnej miłości, dającej maksimum radości i szczęścia. Przy czym miłość małżeńska jest cały czas otwarta na impulsy, które kreowały miłość oblubieńczą. Bodźce i przeżycia $\mathrm{z}$ dwóch pierwszych etapów wręcz są koniecznie potrzebne na trzecim. Ale nie odwrotnie.

2. Miłość jako zakochanie rodzi się dzięki pięknu, które przyciąga, intensyfikuje obecność osoby. Kładąc nacisk na rolę piękna w kreowaniu więzi między nieznanymi sobie dotąd osobami, autor Pnp upomina się o kształtowanie w młodych mężczyznach i kobietach wrażliwości na nie. Oblubieniec dostrzega piękno typowe dla oblubienicy i odwrotnie. Nie ma żadnego pomieszania tych dwóch rzeczywistości. Przy czym nie chodzi o piękno strojów (zewnętrzne, dodane), ale o piękno postaci jako takiej, w którym wyraża się tajemnicza moc przyciągania: ta właściwa mężczyźnie inna od tej właściwej kobiecie. Innym pięknem swego cielesno-duchowego ,ja" oczarowuje oblubienicę oblubieniec, a innym wdziękiem oblubienica tego, w którym odkrywa umiłowanego swej duszy.

3. Miłość emocjonalna (eros) jest bardzo intensywnie obecna w relacji mężczyzna - kobieta, która zachwyca poetę, autora Pieśni nad pieśniami. Poświęca jej bardzo dużo miejsca w tym wyjątkowo krótkim utworze. Zwraca uwagę na rozliczne czynniki, które stanowią o bogactwie tej relacji: inspirujący swym dynamizmem i symboliką taniec, promieniująca „męskość” i ,kobiecość” przenikające osobę umiłowaną, bogactwo i wymiana nieskończonej wręcz liczby darów duchowych symbolizowanych przez nieopisywalny świat wonności, smaków, kolorów, dźwięków. Tym, co rozbudza głębokie emocje, nie jest ,goła” płeć (męska dla kobiety i żeńska dla mężczyzny), ale emanujące z każdej osoby intelektualne, uczuciowe i duchowe energie. Nieskończone bogactwo tych „darów” cielesno-duchowych nie tylko emanuje, ale przenika i napełnia umiłowaną - umiłowanego. Dzięki nim oblubieniec ostatecznie jawi się jako „Adam Boży” (por. Łk 3,38), a oblubienica jako ta, którą sam Stworzyciel przyprowadził do jej Adama (por. Rdz 2,27). Rozlewające się dziś w reklamach i filmach obrazy ukazujące miłość jako magię nagich ciał owładniętych pożądaniem, w istocie odzierają mężczyzn i kobiety z nieskończenie wielkiego bogactwa ich świata duchowego, emocjonalnego i uczuciowego. W procesie wychowawczym należałoby uczyć, jak mężczyźni, a jak kobiety wyrażają swoje uczucia i przeżycia - i w ogóle, jakie one są, ile dają radości i smaku szczęścia.

4. Miłość małżeńska (agape) rozpoczyna się wówczas, gdy oblubieniec i oblubienica podejmują całkowicie wolną decyzję o zjednoczeniu cielesno-duchowym. Ten akt ma cechy typowe dla zawarcia przymierza: dwie strony nieodwołanie przynależą do siebie, co najkrócej wyraża formuła będąca parafrazą formuły 
Przymierza: „mój miły jest mój, a ja jestem jego”. Włącza ich w wielką historię przymierza Boga z ludem, a więc zjednoczenie to ma charakter sakralny, ważny także przed Bogiem i dla Boga. Ma on również charakter „stwórczy” i przemieniający - oto oblubieniec staje się małżonkiem i potencjalnym ojcem, a oblubienica żoną i matką.

5. Miłość w Pieśni nad pieśniami od samego początku ma charakter komunij$n y$ : przyciąga mężczyznę i kobietę do siebie, maksymalnie zbliża i łączy ich światy przeżyć duchowo-emocjonalnych, jednoczy w osobowym akcie cielesno-duchowego zbliżenia. Mężczyzna i kobieta zaangażowani w tę relację nie tylko wychodzą z kręgu dotychczasowej samotności bądź izolacji, ale doświadczają potrzeby dzielenia się i obdarowywania, a zarazem przyjmowania otrzymywanych impulsów i darów. Miłość w Pnp radykalnie wyklucza najmniejszy nawet egoizm, izolację. Tego rodzaju postaw człowiek musi się uczyć od najmłodszych lat.

6. Niezwykle ważny wniosek: miłość jest relacją między mężczyzną i kobietą, a nie między dwoma mężczyznami czy dwoma kobietami. Jakkolwiek starożytny świat znał relacje jednopłciowe, to jednak Pieśń nad pieśniami, będąc wspaniałą syntezą mądrości biblijnego Izraela, niemal w każdej strofie kładzie nacisk na różnorodność: kim innym jest oblubieniec, a kim innym oblubienica. Ta odmienność sprawia, że ich rodząca się i stopniowo intensyfikująca się więź - aż do małżeńskiej - jest dla nich źródłem narastającej radości i szczęścia, które unoszą ich w stronę nieba jak rydwan Aminadaba czy Eliasza. Tylko o takiej miłości natchniony poeta mówi, że jest „mocna jak śmierć”, a ostatecznie zwyciężająca śmierć, bo jest w niej płomień Miłości. Propagowane współcześnie tzw. związki partnerskie czy radykalna zmiana tożsamości otrzymanej od Stwórcy są drogą donikąd. Mogą dostarczać chwilowych przyjemności, zaspokajających różne pragnienia czy namiętności, ale nie są w stanie dać szczęścia, które nadaje sens całemu życiu. Przyjemność tylko zaspokaja pragnienie, a szczęcie płynące z miłości oblubieńczo-małżeńskiej nadaje sens życiu.

7. Miłość w świetle Pieśni nad pieśniami jest darem! Nie można jej kupić. W ostatniej swej pieśni o miłości oblubienica krytykuje wschodnią praktykę małżeństwa zawieranego na podstawie negocjacji między klanami rodzinnymi, nie bacząc na wolę dwojga zainteresowanych. On i ona są dlatego szczęśliwi, a ich miłość zwycięska nawet w obliczu śmierci, ponieważ nie są dobrem handlowym. Darowana sobie wzajemnie miłość, będąca oczarowaniem, a zarazem więzią oblubieńczą i małżeńską przewyższa wszelkie dobra ziemskie i drogocenne perły. Miłość, która kreuje komunię osobową i przemienia oblubieńca i oblubienicę w mężaojca i żonę-matkę, jest łaską, najwyższym doświadczeniem wolności. Ostatecznie 
jest wzajemnym darem. Ale najpierw - tak on, jak i ona - są sobie samym dani przez Stwórcę! Pełne wychowanie do miłości winno prowadzić młodego człowieka do odkrywania i postrzegania siebie jako daru - jako „człowieka od Boga”.

\section{BIBLIOGRAFIA}

Alonso SchöKel, L. (1993). Cantico dei cantici. La dignità del amore. Turyn: Piemme.

BARBIERO, G. (2011). Song of Songs. A Close Reading. Leiden-Boston: Brill.

Bloch, A.-Ch. (2006). The Song of Songs. New York: Modern Library Classic.

LaCocque, A. (2011). Un poema biblico. Il Cantico dei cantici: Nuove letture. Le monde de la Bible, 1, 26-29. Paris: Bayard Presse.

Luzarraga, J. (2005). Cantar de los cantares. Sendas del amor. Estella (Navarra): Verbo Divino.

PÓŁTAWSKA, W. (1981). Przygotowanie do małżeństwa. W: F. ADAMSKI (red.), Milość - malżeństwo rodzina, (s. 21-71). Kraków: WAM.

Ravasi, G. (2005), Pieśń nad pieśniami ... jak pieczęć na twoim sercu. Kraków: Salwator.

Ricoeur, P., LaCocque, A. (1998). Penser la Bible. Paris: Seuil.

WŁodArCzyK, Z. (2011). Rośliny biblijne. Leksykon. Kraków: Instytut Botaniki im. W. Szafera

Polskiej Akademii Nauk.

WoJTYŁA, K. (2001). Miłość i odpowiedzialność. Lublin: TN KUL.

\section{WIZJA MIŁOŚCI MĘŻCZYZNY I KOBIETY \\ W PIEŚNI NAD PIEŚNIAMI. \\ IMPLIKACJE PSYCHOLOGICZNO-PEDAGOGICZNE}

\section{Streszczenie}

Przedstawiona w biblijnej Pieśni nad pieśniami miłość, która łączy mężczyznę (oblubieńca) i kobietę (oblubienicę), stanowi ideał, wolny od negatywnych faktorów zniekształcających lub wręcz przekreślających tę relację. Wydarza się ona między nimi jako realizacja podstawowego powołania, które otrzymali w momencie stworzenia „mężczyzną i kobietą”. To dlatego miłość ta stanowi wyzwanie i szczęście zarazem; ona nadaje najgłębszy sens ich życiu, czyni je pełnym blasku i radości. Oblubieniec i oblubienica przeżywają miłość w trzech wymiarach: oczarowania (zakochania się), erosa i agape. Autor artykułu wydobywa z Pnp to wszystko, co pokazuje ważność każdej z tych sfer oraz ich ponad-naturalne źródło i ukierunkowanie. Ma świadomość, że miłości te wzajemnie się przenikają i niejako stopniowo na siebie się nakładają. Są organicznie ze sobą zintegrowane. W każdej z nich na pierwszy plan wysuwa się właściwy jej dynamizm i odpowiedzialne zań komponenty cielesno-duchowej osoby oblubieńca i oblubienicy. Odkrywając je, możemy dostrzec to, co może rzeczywiście chronić oblubieńczą i małżeńską miłość w czasach współczesnych przed największymi zagrożeniami.

Słowa kluczowe: miłość; Pieśń nad pieśniami; zakochanie się; eros, agape; szukanie; zjednoczenie cielesno-duchowe; stworzony jako mężczyzna; stworzona jako kobieta; wolność wyboru; mąż; żona; ojciec; matka; zagrożenia; szczęście w miłości. 


\title{
THE VISION OF LOVE BETWEEN A MAN AND A WOMAN \\ IN THE "SONG OF SONGS." \\ PSYCHOLOGICAL AND PEDAGOGICAL IMPLICATIONS
}

\begin{abstract}
S u m m ary
The love presented in the biblical Song of Songs, which unites a man (the bridegroom) and a woman (the bride), is an ideal situation free of negative factors that distort or even delete this relationship. It occurs between them as the realization of the basic vocation which they received at the time of their creation as "man and woman." That is why this love is a challenge that at the same time brings them happiness; it gives their lives deepest meaning, making them fully shine with joy. The bridegroom and the bride experience love in three dimensions: enchantment (falling in love), eros and agape. The author of the article takes from the Song of Songs everything that shows the importance of each of these spheres with their their supernatural source and orientation. He is aware that these types of love interpenetrate and gradually overlap each other. They are organically integrated with each other. In each of them, the proper dynamics and responsible components appear, which concern the bodily and spiritual functions of the bridegroom and bride. By discovering these, we can see what can actually protect spousal and marital love in modern times from its greatest threats.
\end{abstract}

Key words: love; Song of Songs; falling in love; eros; agape; searching; corporal-spiritual union; created as a man; created as a woman; freedom of choice; husband; wife; father; mother; threats; happiness in love. 